\title{
THE ROLE OF CONTROLLING AND ITS ADMISSION WITHIN SMS ENTERPRISES IN HUNGARY - ESPECIALLY IN THE HOSPITALITY INDUSTRY
}

\author{
László Papp ${ }^{l}$ \\ Andor Pajrok ${ }^{2}$
}

\begin{abstract}
In last decades, international competition has become an increasingly important factor in many industries. Managers in the new environmental demands need more relevant cost and performance information on the organization's activities, processes, products, services and customers. This article is an attempt to identify and investigate the role of Controlling and its implementation within hungarian SMS Enterprises in the Hospitality Industry.
\end{abstract}

Key words: Controlling, Competitiveness, USALI

JEL Codes: L21

\section{Introduction}

In last decades, managers faced that companies' environment has become more changeable than ever, moreover globalization has increased competitive pressure on firms. Companies must be flexible to respond rapidly to competitive and market changes. To do so, managers require adequate and accurate information. Financial information plays a very important role in the decision making process, because it helps managers to find necessary decisions and actions, and to contribute to improving of the shareholders' value.

This article is an attempt to identify and investigate the role of Controlling to improve companies' chance to achieve higher level of business success. Controlling is one of the most effective management function that can serve with adequate and accurate internal financial information to managers about the company's real position.

\section{Value creation to manage the success in the competitive world}

Professions (Scott-Lodge, 1985; Dertouzos et al, 1989; Török, 1996) argue that the concept of competitiveness can be applied at different levels, they speak about international, national, regional, industrial, company or product level. In our point of view competitiveness is regarded on the company's level. Michael Porter's framework about competitiveness is one of the most widespread and educative ones. Porter's (1980) familiar „five forces of competition” model identifies the basic sources of competition on the company and product level. ${ }^{3}$ The five forces industry competitors, substitutes, potential entrants, suppliers and buyers - lie within the domain of the company's competitive micro environment. According to his opinion company's competitiveness lies on innovation based - cost advanced or differentiation - competitive edges. ${ }^{4}$

Experts (Porter, Pisano and Hayes, Fisher, Collins and Montgomery) agree that in order to survive the competition, companies have to set up theirs own individual strategy. Strategy requires managers to look forward as well. Corporate strategy collects tools and points out the right direction

\footnotetext{
${ }^{1}$ University of Pécs, Hungary, papplaszlo.b@gmail.com

${ }^{2}$ Eötvös József College, Baja, Hungary, pajrokandor@hotmail.com

${ }^{3}$ In his later works he laid down that only source for national competitiveness can be the national productivity, which based on knowledge and information [Deák (2000)].

${ }^{4}$ Michael E. Porter (2006): Versenystratégia; Akadémiai Kiadó; Budapest; pp. 55.
} 
which helps company to achieve strategy goals. According to Porter's approach "Competition strategy is about being different. It means deliberately choosing a different set of activities to deliver a unique mix of value." Figure No. 1. shows Porter's basic approach about value creation in the competitive environment.

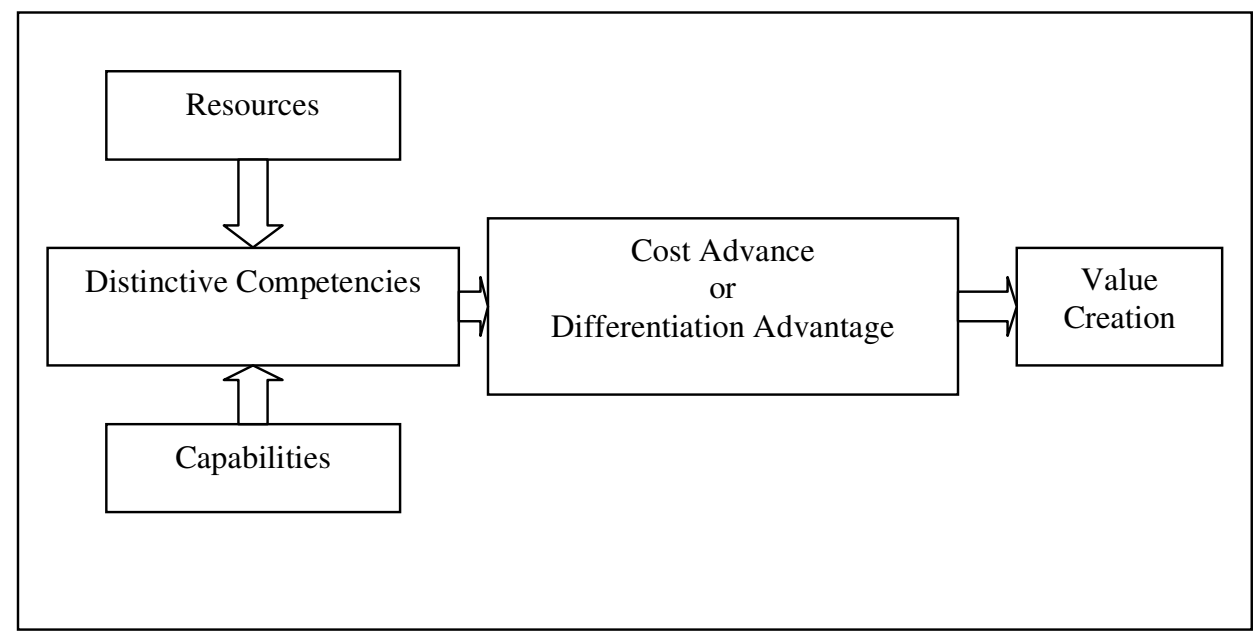

Figure No. 1.: Porter's model of Competitive Advantage

Source: M. E. Porter, 1985. Competitive Advantage, The Free Press; New York;

The concept of value creation is the core of management, since superior value on vis-à-vis rivals and the ability to capture parts of this value in the form of profits are prerequisites for building competitive advantage. Competitive advantage is the basis for reaching the fundamental goal of a company: long-term sustainable success.

At this point, it is important to clarify the definition of value. In more disciplines experts tried to define the terminology of value. In the economics term marketers and financial expert's opinion has increased. On one hand, the concept of value for classical marketers (Kotler, 2000) means customer value; on the other hand in value based literature (Doyle, 2002; Rappaport, 1998; Copeland-Koller-Murin, 1990) it could be thought that the shareholder value is the central point of a value theory. They consider customer value as a tool to achieve and increase a shareholder value. ${ }^{6}$

As it is seen from above, customers are the key for companies. Satisfied customers mean the companies' cash-in (source of funds) for long time period. Kotler (2000) explains customer value in this way: „Total customer value is the bundle of benefits customers expect from a given product or service. Total customer cost is the bundle of costs customers expect to incur in evaluating, obtaining, and using the product or service. Customer delivered value is the difference between total customer value and total customer cost." 7 Therefore, the key is to maximize customer delivered value. Clearly, this can be achieved by offering greater total customer value as well as by making products available at a lower total customer cost.

Porter (1985) states that ,value is what buyers are willing to pay, and superior value stems from offering lower prices than competitors for equivalent benefits" he subsumes the similar yet conceptually distinct concepts of perceived use value and consumer surplus in one term. According to Bowman and Ambrosini (2000), perceived use value is defined as ,a price that a customer is

\footnotetext{
${ }^{5}$ Michael Porter (1996): What is a strategy?; Harvard Business Review; November-December; pp. 64.

${ }^{6}$ In last decades more and more company start to use share value to measure a strategic and management's performance.

${ }^{7}$ Kotler, P. (2000): Marketing Management, International Edition, Prentice Hall, Englewood Cliffs, NJ, pp. 35.
} 
prepared to pay for the product if there is a single source of supply". It is important to notice that the perceived use value depends entirely on the individual customer's subjective perception.

We can conclude that authors agree that value is what customers are willing to pay. Following this judgment, higher value can arise from company's ability to realize lower production cost, or its product differentiation. In practice, Porter's (1985) value chain concept ${ }^{8}$ has increased to identify which company's factors affect the value. ${ }^{9}$ The writer starts his interpretation from the market position of product, which is an interaction of offered utility to customers, and company's production cost. Offered utility largely determines the realizable margin by company; while the company's production cost (structure, margin) decides the quantity of production. From these two effects company can realize the value which customers are willing to pay.

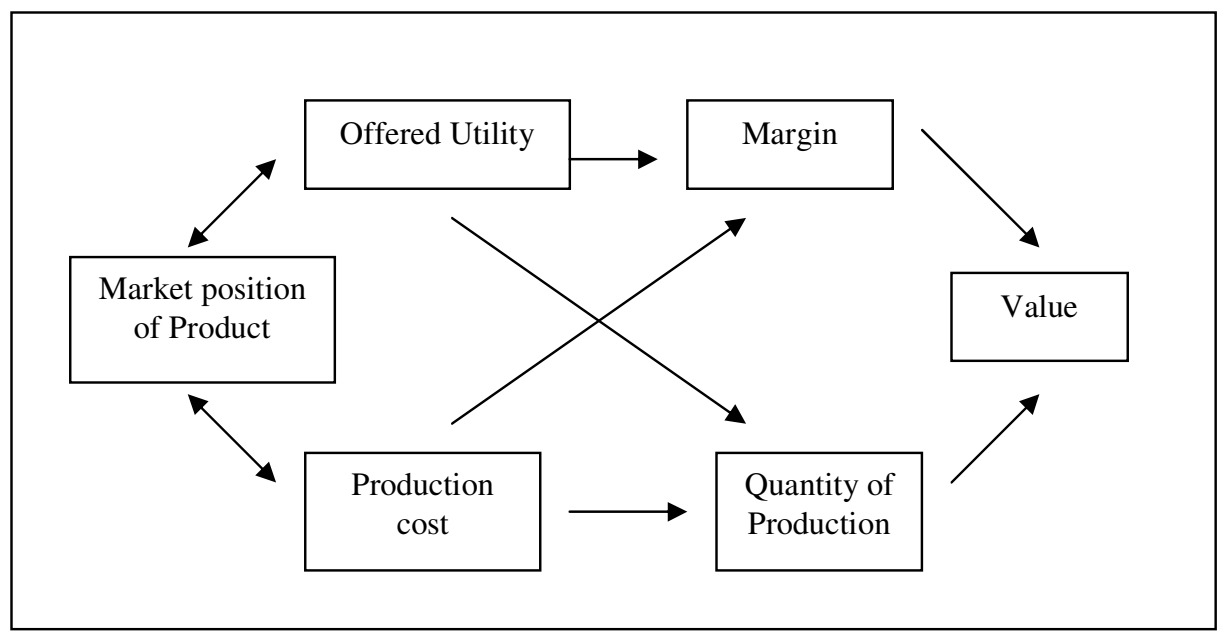

Fig. no. 2 - Company's factors that affects to the value creation

Source: Czakó Erzsébet, 2003. Érték az üzleti stratégiában - a Porteri koncepciók és változásai; Vezetéstudomány; XXXIV. Évf.

As for the value chain analysis is concerned, it could be seen that for value creation managers need to possess adequate and accurate information. This information can arise from company's accounting department. Updated Accounting Act in Hungary declares that companies have to report the financial statement of their performance from actual business years. ${ }^{10}$ According to Copeland to understand value creation one must use a long-term strategic point of view, manage all cash flows on the income statement and the movements on the balance sheet, and one must know how to compare cash flows from different time periods on a risk adjusted basis. It is therefore impossible to make good decisions without complete information, and according to Copeland there is no performance metric other than value that uses complete information (Copeland at all, 1990). The value relevance of accounting information stressed Hellströn (2006), in her work in which she pointed out that value relevance of accounting information in transitions economy (like Hungarian) also exists and is important.

\footnotetext{
${ }^{8}$ Michael E. Porter (1985): Competitive Advantage; The Free Press. New York;

${ }^{9}$ Michael Porter introduced the concept of the Value Chain. He suggested that activities within the organization add value to the service and products that the organization produces, and all these activities should be run at optimum level if the organization is to gain any real competitive advantage. If they are run efficiently the value obtained should exceed the costs of running them i.e. customers should return to the organization and transact freely and willingly. Michael Porter suggested that the organization is split into ,primary activities” and ,support activities”.

${ }^{10}$ According to the Hungarian Accounting Act Financial Statement include: Balance Sheet, Income Statement and Notes.
} 
Weston and Brigham (1993) pointed out that analysis made of accounting information can serve favor „needle" role to managers to find a right way for a company's permanent goal. Financial information for managers can be provided by Controlling.

\section{Role of Controlling}

Controlling has a lot of definition. Controlling can be connected to the organizational management. In this approach, controlling can be thought as a management function. In the management science it is a generally accepted fact that Henry Fayol (1916) was the first who identified the management functions. He pointed out that activities in each organization can be clearly dividing into six general areas, as follows: Technical, Commercial, Financial, Security, Accounting and Managerial. As a managerial activity Fayol concluded that managers have to posses five functions. ${ }^{11}$ The five functions are: Planning, Organizing, Commanding, Coordinating and Controlling. Controlling in Fayol's approach is described in the sense that a manager must receive feedback on a process in order to make necessary adjustments.

Robert N. Anthony's (1965) classical definition of controlling is one of the most common in the business literature. He defined management control as ,the process by which managers assure that resources are obtained and used effectively and efficiently in the accomplishment of the organization's objectives." He saw management control as a linkage between processes of strategic planning and operational control ${ }^{12}$, these processes being superimposed upon an organization hierarchy to indicate the respective managerial levels at which they operate. Management control in Anthony's approach can be seen as processes that deal with organizational operations, and the main goal are the effective and efficient resources utilization. Effectiveness and efficiencies are measured by fruition of organization's goals, and the main measurement tool is money value which is based on accounting information.

A broader view of management concept suggested by Lowe (1971) in a more comprehensive definition is: „A system of organizational informational seeking and gathering, accountability and feedback designed to ensure that the enterprise adapts to changes in its substantive environment and that the work behavior of its employees is measured by reference to a set of operational sub-goals (which conform with overall objectives) so that the discrepancy between the two can be reconciled and corrected for." "From the definition it appears that Lowe stressed the role of management control system as a broad set of control mechanisms designed to assist organizations in order to regulate themselves.

The International Group of Controlling (IGC) offers the subsequent definition: ${ }^{14}$ Controllers design and accompany the management process for defining goals, planning and controlling and thus have a joint responsibility with the management to reach the objectives. This means:

- Controllers ensure the transparency of business results, finance, processes and strategy and thus contribute to higher economic effectiveness.

- Controllers co-ordinate sub-targets and related plans in a holistic manner and organize a reporting-system which is future-oriented and covers the enterprise as a whole.

- Controllers moderate and design the controlling process for defining goals, planning and management control, so that every decision-maker can act in accordance with agreed objectives.

- Controllers provide managers with all relevant controlling information.

\footnotetext{
${ }^{11}$ This was later shortened down to the four in PLOC (Planing, Leading, Organising and Controlling).

${ }^{12}$ On one hand, strategic planning is concerned with setting goals and objectives for the whole organization over the long term. On other hand, operation control is concerned with the activity ensuring that immediate tasks are carried out. Management control is that links the two.

${ }^{13}$ Lowe E. A. (1971): On the Idea of a Management Control System: Integrating Accounting and Management Control; Journal of Management Studies; pp. 5.

${ }^{14}$ www.igc-controlling.org, download: 21.rst of September 2010.
} 
- Controllers develop and maintain controlling system.

\section{Information source of Controlling}

The controlling inputs consist of external and internal data and information. Internal data and information are based on accounting data. The management requires more detailed information than what conventional financial accounting can offer, because the focus of the management lies rather on the future than on the past. For a businessman who manufactures goods or renders services, cost accounting is a useful tool. Cost accounting is a mechanism of accounting through which cost of goods or services are ascertained and controlled for different purposes. It helps to ascertain the true cost of every operation, through cost analysis and allocation.

The management accounting can be seen as an extension of the horizon of cost account. Management accounting is concerned with providing economic information for managers to achieve organization goals. The basis of fundamental objective of management accounting is to enable the management to maximize profits or minimize losses. They provide useful information in planning processes; in the interpretation of the process; they assist in decision-making process; reporting; etc.

We can conclude that information provided by cost accounting is primarily useful for managers at a lower level of hierarchy, whose aim is to bring an optimal decision within the given goals, resources and activity alternative framework. The top managers need information so they can better satisfy management accounting whit its future-oriented focus (Zéman, 2010).

\section{Uniform System of Accounts for the Lodging Industry}

Managerial accounting is the framework for development of responsibility accounting, which is based on specifics of hospitality industry and accounting standards of the „Uniform System of Accounts for the Lodging Industry" (USALI). The Uniform System of Accounts for the Lodging Industry was published by the Hotel Association of New York City ${ }^{15}$ in an attempt to establish a uniform accounting system for member hotels. The document reflects its cost accounting view, because the appearance of the document was the answer to the management needs (Kwansa et all, 1999). Cost controls are always important becouse they are the keys to profits. In order to operate profitably, manager of the hotel and services units must be cost conscious and aware of the need for cost control. To do so, USALI's principle is that each manager should be responsible for revenues and costs that are able to control. According to the experts (Kotas et al, 1997; Ferrara et al, 1991) responsibility accounting is an accounting system which emphasizes the human element and its effects on operation. Responsibility accounting stresses the control or influence that managers can exert within the segment of the organization for which they are responsible. As companies in hospitility service industries became more decentralized, responsibility accounting system evolved becouse of the increased need to communicate operating results through the managerial hieracrhy. The responsibility reports about unit performance are primarily tailored to fit the planning, controlling and decission-making needs of subordinate managers. A primary objective of responsibility accounting is to determined the cost of products made or the services performed by an organization.

Segment reporting is fundametal for management accounting, while its organisation and content should be organized in such way to help the financial statements users to understand better the efficacy of previous periods, to make a better assessment of risk and possibilities of the enterprise and a more realistic assessment of the firm as a whole. A hotel being an investment center, the operated departments like rooms, food, beverage and other services as a profit centers that present an unavoidable information basis in the organisation, informative, accounting and information aspect. On these standpoints it is possible to define the flow of goods, money and

\footnotetext{
${ }^{15}$ The first edition of the uniform system for hotels was issued in 1926. It was one of the earliest attempts by any
} industry in the United States to create guidelines for preparing accounting standards and financial reporting practices. 
information, and optimise the input, content and output of data and information in the management accounting. Figour No. 3 show the model of the Hotel Enterprise.

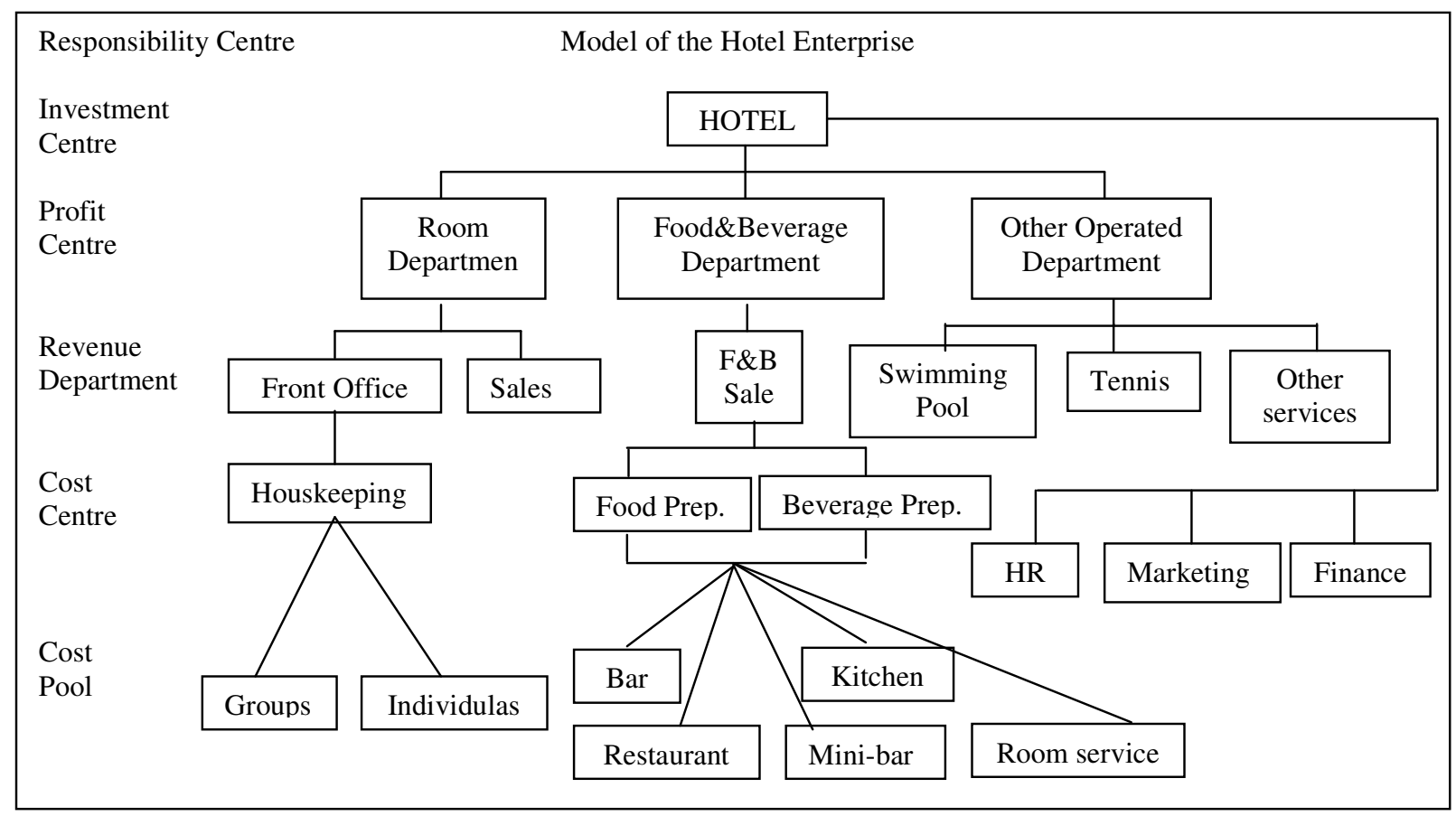

Fig. no. 3 - Responsibility Centres like Prerequisite for the Establishment of the Responsibility Accounting

Source: Turčić, M, 2001. The System of Accountancy Reporting of the Hotel Management, MS Thesis, Faculty of Economics Zagreb, pp. 57.

A responsible manager has an insight into the expenses/revenues that are within his competence. The first level of the internal result is the difference between revenues of those segments cost, that operated their activities directly on the external market and expenses of the same operated departments presented as the profit from operated departments or contribution margin. The variable costs at this level are controllable operation expenses ${ }^{16}$ that are deducted from the revenue to establish the gross operating income. If we deduce from the first level profit the part of fixed cost that can be immediately calculated into the particular business operation, we can establish gross operation profit. The manager can not significantly influence the third level of results, the net operating profit. The uncontrollable overheads (rent, property taxes, insurance, interest expense, depreciation and amortization) are compensated on this level. The head manager controls this category of cost, because it is the result of his decision.

Kwansa and Schmidgall (1999), in a recent survey in lodging controllers determined that $76 \%$ of lodging operations were using the USALI but only $11 \%$ of these controllers responded that the were following it all the time, while $65 \%$ indicated ,in most of the times".

\section{Operative controlling and strategic controlling}

As it is seen from above, management control makes a linkage between operational and strategic level. At strategic level managers tasks are connected with planning - setting goals and

\footnotetext{
${ }^{16}$ These are the expenses that can not relate immediately to the output unit, but are possible to relate to the department, its property and its operations, so they are controllable overheads (administrativ and general department cost, advertising and marketing, heating, maintenance, and so on).
} 
objectives for the whole organization over the long term. At the operational level managers (operation control) are concerned with the activity ensuring that immediate tasks are carried out. In this term we can speak about operative and strategic controlling [Horvath\&Partners (2003)].

Operative controlling is professional support for a line and medium management the goal of which in the distance or near future is to increase a business' efficiency and its level of potential in the following fields: profitability, economy, preservation of substance and liquidity, and coherent utilization of operative management instruments. The objective of operative controlling is the promotion of passive adaptation to changing environment, i.e. adaptation of influences to internal factors. Operative controlling is aimed at measurable and controllable manifestations and processes in a company's business.

Strategic controlling offers professional support for top management with the aim of increasing business effectiveness. It focuses on building up potential for the company's future success, strengthening the company's vitality, and improving the probability for its permanent success. Strategic controlling should provide professional support for various issues, including: whether the company should introduce a new product, or enter into a new market; the kinds of risks and opportunities that may be expected in the future; whether the company should innovate a technological process by investment, etc. Strategic controlling helps in the designing of vision, a mission, goals and a strategy for permanent company success. The importance of strategic controlling is active adaptation, i.e. influencing external factors and changing the environment to suit particular needs.

\section{Industry}

Controlling application within SMS Enterprises in Hungary in the Hospitality

Today, relatively few studies exist about Controlling applications within Tourism Firms. This sense is more to emphasize transition economies, like Hungarians. Bodnár (1997) stressed out that within Hungarian firms Controlling appeared in the end of the 80's. At this time the main function of Controlling was to follow operative performance of the firm, it was past oriented and could not be able to support manager decisions. With switching-over to market economy role of accounting has been changed inside the firm. The appearance of foreign consultants was conductive to spreading Controlling between Hungarian firms. With the new approach, they brought a management support Information Technology.

Hotel Association of Hungary discloses that Hungarian Tourism Firms are rather Small and Medium Sized (SMS) Enterprises. Katona (2005) in his work examined - strategic and operative controlling tools ${ }^{17}$ applications within SMS Enterprises in Hungary. He laid down that many of SMS enterprises are not mindful these tools and the importance of Controlling.

Beside initial tendencies recognized among the big sized companies, recent researches (Zéman-Fónagy, 2008; Zárda, 2009) show that SMS Enterprises in Hungary use financial accounting based indicators for evaluation of company performances, rather than value-based indicators.

Fónagy (2008), in a recent survey, that included 400 SMS Enterprises, examined the number of used performance indicators among SMS's in Hungary. According to research most of SMS's use between 4 and 7 indicators to evaluate there operation. Figure No. 4. shows the No. of used performance measurement indicators within SMS Enterprises in Hungary.

\footnotetext{
${ }^{17}$ On one hand, Katona in his work regard strategic controlling tools like SWOT analyses, Portfolio analyses, GAP analyses, Benchmarking, Scenario technics; but on the other hand operative tools are Contribution analyses, Target Cost analyses, Proces Cost analyses.
} 


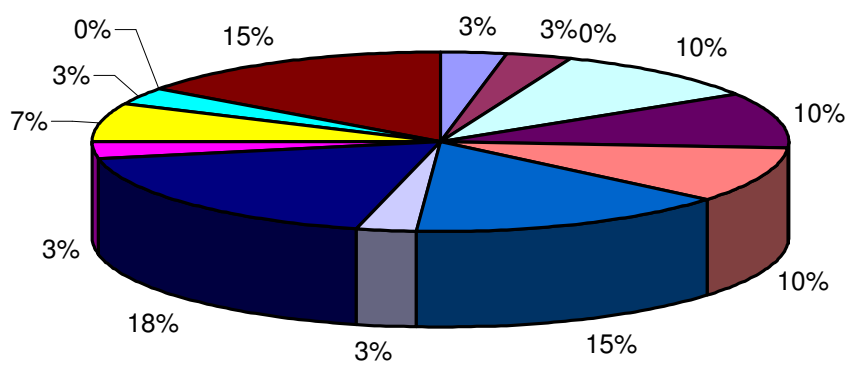

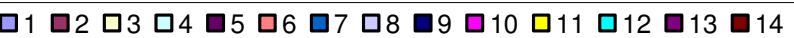

Fig. no. 4 - No. of performance measurement indicator used within SMS Enterprises in Hungary

Source: Zéman Zoltán 2010. Controlling versus Számvitel, "Pénzügyi Mágiák - Pénzügyi Kiutak” Professional Conference at the University of West Hungary, Faculty of Business and Economics, Sopron, Hungary, 30.09.01.10.2010.

As figure No. 4. shows, for the evaluation of performance only 3 percent of SMS's use 1 indicator, 15 percent of SMS's use 14 indicators, but most of them (18\%) use 9 indicators.

The result of the research also shows, that companies prefer to use conventional financial accounting based indicators to evaluate their performance like: Profit Before Tax - PBT (83\%), Income and Earnings Before Interest and Tax - EBIT (73\%), Earnings Before Interest, Tax, Deprecation, Amortization - EBITDA (70\%), Return on Asset - ROA (67\%), Return on Equity ROE (63\%). The most popular value-based performance measurement indicators are the Economic Value Added - EVA (47\%), NOPAT (60\%) and ROCE (63\%). Figure No. 5. shows the used performance measurement indicators within SMS Enterprises in Hungary.

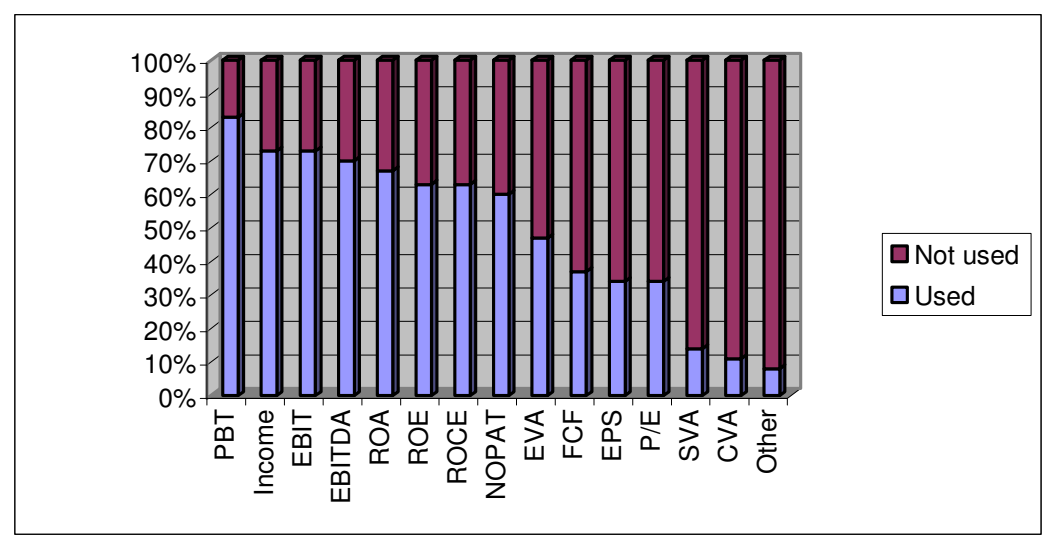

Fig. no. 5 - Used performance measurement indicators within SMS Enterprises in Hungary

Source: Zéman Zoltán 2010. Controlling versus Számvitel, "Pénzügyi Mágiák - Pénzügyi Kiutak” Professional Conference at the University of West Hungary, Faculty of Business and Economics, Sopron, Hungary, 30.09.01.10.2010.

A significant number of experts are oriented to the Hotel Industry in their investigations. One of the most coherent studies on Controlling application coming from transition economies is the one by Osmanagic-Lavovac (2007). In their work, they investigate the interdependency between business success and the existence of controlling departments within companies in Croatia. In their 
empirical research they encompass 32 of the 406 existing hotel companies in Croatia. The sample represents $35 \%$ of the total hotel beds; realize $44 \%$ of the total achieved revenues in hotel companies; employed $37 \%$ of the total hotel staff in Croatia and include $21,9 \%$ state companies and $78,1 \%$ private companies. The survey pointed out that controlling exists in $31 \%$ of hotel companies. Their comparative analyses confirm that companies with controlling department achieved better liquidity (Current ratio, Working Capital, Operative Cash flow, Net Cash flow) and higher business success ratios (Economic, EBITDA, ROI) then those with no controlling department.

\section{Conclusions}

This paper emphosises the role of Controlling, whith the primary aim to imporve the companies competitiveness. Porter in his work attends, that companies can achieve competitiveness by using cost advanced or differentiation advantage strategies. The main role of Controlling is to deliver information towards Management. Controlling represents a function within a management system which increases its effectiveness and efficiency, and thereby its ability to assimilate changes within a company and out of it.

This paper explores admission of Controlling within SMS Enterprises in Hungary, and concludes that SMS's in Hungary still not adapted Controlling admissions inspite the fact that it could be the source of competitiveness. The sequitur of this paper is that Controlling seem to be indispensable management function in the XXI. century. The investigations show that in transition economies firms are not mindful of the role of Controlling, although the importance of it is verified within Tourism Firms, too.

\section{References}

1. Alfred Rappaport, 1986. Creating Shareholder Value: The New Standard to Business Performace; Free Press; New York

2. Alfred Rappaport, 1998. Create Shareholder Value - A Guide for Management and Investors; The Free Press

3. Anne Ameels-Werner Bruggeman-Geert Scheipers, 2002. Value-Based Management control processes to create value throughout integration a literature review; Vlerick Leuven Gent Management School

4. Bodnár Viktória, 1997. Menedzsment Kontroll, Controlling, Vezetői Számvitel: Nemzetközi elmélet és gyakorlat - hazai tapasztalatok; A controlling vezetési megközelitése; Vezetéstudomány; XXVIII. évf.; 05. Issues; pp. 3-12.

5. Bowman, C. and Ambrosini, V., 2000. Value Creation versus Value Capture: Towards a Coherent Definition of Value in Strategy; British Journal of Management 11; pp. 1-15.

6. Czakó Erzsébet, 2003. Érték az üzleti stratégiában - a Porteri koncepciók és változásai; Vezetéstudomány; XXXIV. Évf.; 05. Issues

7. Deák Szabolcs, 2000. A Porter-féle Rombusz-modell föbb gazdasági összefüggései; in Farkas B. - Lengyel I. (authors): Versenyképesség - regionális versenyképesség; SZTE Gazdaságtudományi Kar Közleményei; JATEPress; Szeged

8. David J. Collins-Cynthia A. Montgomery, 1995. Competing on Resources: Strategy in the 1990s; Harvard Business Review; July-August; pp. 118-128.

9. Geoffrey I. Crouch and J. R. Brent Ritchie, 1999. Tourism, Competitiveness, and Societal Prosperity; Journal of Business Research 44

10. Katona Ferenc, 2005. A marketing-controlling lehetőségei a kis- és középvállalatok versenyképességének növelésében; College of Dunaújváros, Hungary, Institute of Economics

11. Keith Ward, 2004. Marketing Finance, Turning Marketing Strategies into Shareholder Value; ELSEVIER, Butterworth Heinemann 
12. Kotler, P., 2000. Marketing Management, International Edition, Prentice Hall, Englewood Cliffs, NJ,

13. Kwansa, F. and Schmidgall, R., 1999. The Uniform System of Accounts for the Lodging Industry, The Cornell Hotel and Restaurant Administration Quartely, Vol. 40., No. 6, pp. 88-94.

14. Lowe E. A., 1971. On the Idea of a Management Control System: Integrating Accounting and Management Control; Journal of Management Studies; pp. 1-12.

15. Hellströn Katerina, 2006. The value relevance of Financial Accounting Information in a Transition economy: The case of Czech Republic; European Accounting Review; Vol. 15; No. 3.; pp. 325-349.

16. Horváth\&Partners, 2003. Controlling, Út egy hatékony controlling-rendszerhez; KJKKerszöv Jogi és Üzleti Kiadó Kft; Budapest

17. Michael E. Porter, 1985. Competitive Advantage; The Free Press. New York;

18. Michael E. Porter, 1996. What is a strategy?; Harvard Business Review; NovemberDecember; pp. 61-78.

19. Michael E. Porter, 2006. Versenystratégia; Akadémia Kiadó; Budapest

20. Osmanagić, N. B. - Lalovac, B., 2007. Controlling - Factor for business success an example from the Hotel Industry; Acta Turistica, Vol. 19.; No. 1.; pp. 83-99.

21. Peter Doyle, 2002. Értékvezérelt Marketing, A részvényesi értéket és a vállalati növekedést támogató marketingstratégiák; Panem Könyvkiadó Kft. - John Wiley \& Sons Ltd., Budapest, 2002.

22. Robert H. Hayes and Gary P. Pisano (1994): Beyond World Class: The New Manufacturing Strategy; Harvard Business Review; January-February; pp. 77-86.

23. Robert N. Anthony - Vijay Govindarajan, 2003. Management Control System; 11ed; McGraw-Hill Companies, Inc.

24. Scott, Bruce R. and Lodge, George C., 1985. U.S. Competitiveness in the World Economy; Harvard Business School Press, Boston

25. Teemu Malmi-Seppo Ikaheimo, 2003. Value Based Management practices-some evidence from the field; Management Accounting Research 14; pp. 235-254

26. Tim Copeland - Tim Koller - Juck Murrin, 2000. Valuation: Measuring and Managing the Value of Companies; McKinsey\&Company, Inc.

27. Török Ádám, 1996. A versenyképesség-elemzés egyes módszertani kérdései; mühelytanulmány, Budapest

28. Turčić, M, 2001. The System of Accountancy Reporting of the Hotel Management, MS Thesis, Faculty of Economics Zagreb

29. Uniform System of Accounts for the Lodging Industry, 9th Edition, Educational Institute of the American Hotel \& Motel Associaton, East Lansing, Michigen, 1996

30. Zéman Zoltán 2010. Controlling versus Számvitel, "Pénzügyi Mágiák - Pénzügyi Kiutak" Professional Conference at the University of West Hungary, Faculty of Business and Economics, Sopron, Hungary, 30.09.-01.10.2010.

31. www.igc-controlling.org 